\title{
Honey Value Chain at Al Osaimat District in Ammran Governorate, Yemen
}

Received: 30 March 2021

Revised: 25 April 2021

Dr. Maher Abdulla Moharram ${ }^{(1, *)}$

Accepted: 10 June 2021

(c) 2021 University of Science and Technology, Yemen. This article can be distributed under the terms of the Creative Commons Attribution License, which permits unrestricted use, distribution, and reproduction in any medium, provided the original author and source are credited.

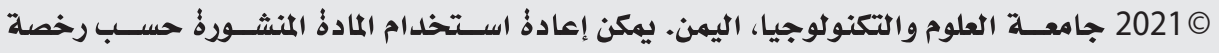
مؤسسة المشاع الإبداعي شريطة الاستشهاد بالمؤلف والمجلة.

\footnotetext{
1 Assistant Professor of Business Administration, Collaborated Programs Department, University of Science and Technology, Yemen

* Corresponding author: dr.maherpage@gmail.com
} 
Honey Value Chain at Al Osaimat District in Ammran Governorate, Yemen

\section{Abstract}

Due to its varied ecological and climatic conditions, Yemen has a favorable natural resource endowment for the beekeeping and comparative advantage in the production of honey. Al Osaimat is not an exception where Al Osaimat honey is a well-known brand name inside and outside Yemen. Value chain development is a growing approach used worldwide to increase incomes of small producers and the economically active poor families. This study aimed to investigate the flow of honey production by exploring the status of the value chain and identifying the opportunities and constraints in the chain, where appropriate interventions are possible to minimize the chain risks and maximize value. A sample of 72 beekeeping households was surveyed, and for the deeper understanding of the state of honey chain, two focus group discussions and key informant interview were conducted. The results showed the absence of any official attention to the apiculture in the area and the lack of proper training to the chain actors, the domination of oldfashioned beekeeping practices, and the non-availability of supportive actors particularly the financial institutions. Furthermore, the study summarized the seven most important constraints and recommended intervention(s) for the value chain development.

Keywords: Al Osaimat honey, marketing channels, value chain, Yemen. 


\section{سلسلة قيمة العسل في منطقة العصيمات بمحافظة عمران - اليمن}

الملخص:

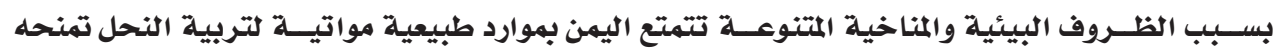

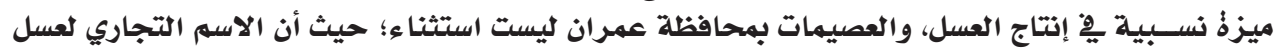

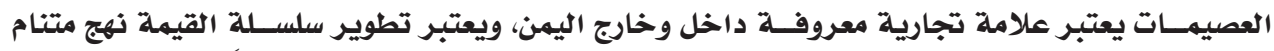

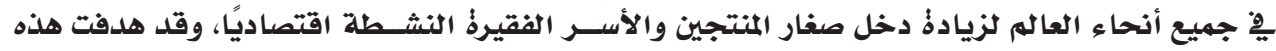

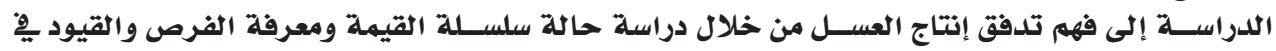

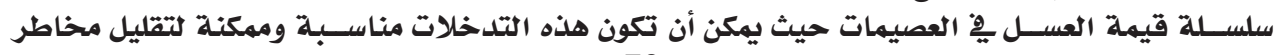

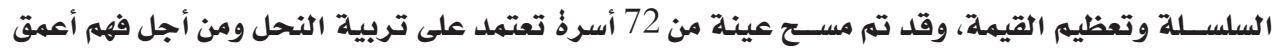

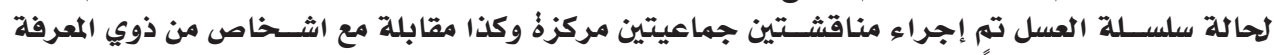

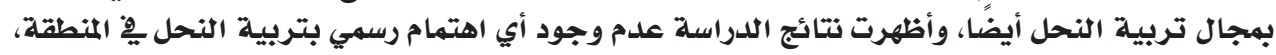

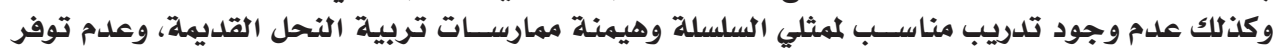

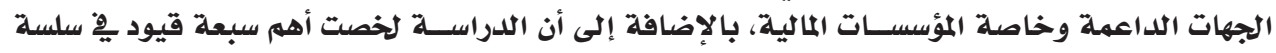
القيمة والتدخلات الموصى بها التواتل التطوير سلسلة القيمة.

الكلمات المفتاحية : عسل العصيمات، قنوات التسويق، سلسلة القيمة، اليمن. 


\section{Introduction}

Yemen is among the major producers of honey in the Arab world and in the Arab Peninsula in particular. According to the Federation of Yemeni Beekeepers, Yemen exported 50,000 tons of honey per year before the war took place in 2015, but exports have since fallen by more than 50\%, and there are around 100,000 people working in honey farms (Reuters, 2018). There are many honey production areas in Yemen and Al Osaimat District is one of them. Al Osaimat is an undeveloped geographical district of Ammran Governorate in the north of Yemen. It has a rich natural resource base for the production of honey and other apiculture products particularly Jujube trees (Ziziphus Spina-Christi known as Christss thorn jujube) which is a source of Sidr honey, the premium Yemeni honey inside and outside Yemen. Beekeeping in Al Osaimat is a very old profession, and has recently gained commercial famous and Osaimat honey is its brand name. Although beekeeping has been practiced for a long period in Yemen, this profession is still dominated by the traditional production system.

Al Osaimat apiculture has many challenges like bee disease and lack of proper business practices (personal communication with beekeepers, the day, month and year); the absence of government support leads to major drawbacks such as lack of necessary knowledge and skills among beekeepers, substandard veterinary and extension services, non-availability of access to capital, inadequate equipment, underdeveloped support services, and limited infrastructure. All these challenges result in the slow development of the sector and prevent it from becoming a truly leading component of a wellestablished business. The Royal Tropical Institute and the International Institute of Rural Reconstruction, Nairobi-KIT \& IIPP- emphasized that the value chain development is a growing approach worldwide used to increase incomes of small producers and the economically active poor (KIT \& IIRR, 2010). The importance of this study stems from the criticality of understanding the honey value chain in Al Osaimat as to identify the different market channels that honey production takes before reaching the end consumer; that is, to identify bottlenecks, along with potential opportunities that may not be apparent otherwise. By understanding the chain constraints and opportunities, and designing appropriate interventions as projects or programs, this can assist to provide support to some value chain actors to achieve the desired development outcome which eventually helps as poverty-reduction in the target area. A value chain is the entire system of production, processing, 
and marketing of a particular product, from inception to the finished product and its end-use. KIT and IIRR (2010) defined the value chain as a series of chain actors, linked together by flows of products, finance, information, and services. According to Kaplinsky (1999), value chain describes the full range of activities that are required to bring a product or service from conception, through the intermediary phases of production (involving a combination of physical transformation and the input of various producer services), delivery to final consumers, and final disposal after use. Therefore, the value chain is a basic tool for diagnosing competitive advantage and finding ways to create and sustain it (Porter, 1998).

This study aimed to investigate the flow of honey production through exploring the status of honey value chain and identifying the opportunities and constraints in the chain, where appropriate interventions are possible to minimize the chain risks and maximize value. This may lead to improve the chain members' business practices, resilience, and household income and ultimately result in poverty alleviation.

\section{Value chain}

The idea of a value chain was first suggested by Porter (1985), to depict how customer value accumulates along a chain of activities that lead to an end product or service. The term value chain refers to the full range of activities that are required to bring a product (or a service) from conception through the different phases of production to delivery to final consumers and disposal after use (Kaplinsky \& Morris 2001).

A value chain is a supply chain made up of a series of actors-from input suppliers to producers and processors to exporters and buyers-engaged in the full range of activities required to bring a product from its conception to its end use (Kula, Downing, \& Field, 2006).

\section{Value chain analysis}

Value chain analysis can be used to identify and target interventions aimed at improving the quality and distribution of specific product in the system. It is the process of looking at the activities that go into changing the inputs for a product or service into an output that is valued by the customer (Porter, 1988). 


\section{Value chain development}

Value chain development is a positive or desirable change in the value chain to extend or improve productive operations and generate social benefits: poverty reduction, income and employment generation, economic growth, environmental performance, gender equity and other development goals (UNIDO, 2011).

\section{Honey value chain in Yemen}

Key concepts related to value chain development are win-win relationships, upgrading, innovation, and added value. Pro-poor value chain development has been defined as a "positive or desirable change in a value chain to extend or improve productive operations and generate social benefits: poverty reduction, income and employment generation, economic growth, environmental performance, gender equity and other development goals" (UNIDO, 2011, p. 1).

The International Fund for Agricultural Development(IFAD), in the development of Sri Lanka's rubber value chain, confirmed that the development of the chain led to a number of specific development goals, particularly poverty reduction and income generation for small rubber producers, especially women (Henriksen, Riisgaard, \& Ponte, 2010).

Concerning Yemen, searching secondary government data for honey value chain shows no record of prominent studies. In 2009, the World Bank Agricultural and Rural Development Team as part of its ongoing work on agricultural development in Yemen - Pathways out of rural poverty studycommissioned a study to assist the Ministry of Planning and International Cooperation (MOPIC) of Yemen in assessing the efficiency and competitiveness of the selected value chains. The study was conducted by the Small Micro Enterprise Promotion Service (SMEPS) from Yemen in cooperation with the Royal Tropical Institute (KIT) from the Netherlands. The study aimed to analyze 5 value chains in Yemen (i.e. Fish, Honey, Coffee, Wheat, and Qat). For the honey value chain, the study selected four governorates: Hadramout, Abyan, Hodiedah, and Ammran while the present study focuses only on the most famous Sidr honey producing area in the northern of Yemen (Al Osaimat District in Ammran Governorate). Another study conducted by The International Fund for Agricultural Development (IFAD) in 2008 upon a request from the Yemeni Government found that honey constitutes (6\%) of the agricultural export (IFAD, 2008). The study indicated that the price 
of Yemeni honey was among the highest in the world. Yemeni honey was high priced on the international market and attracts lucrative prices, between 2001 and 2007; the average price was between three and five times the average price of the world's twenty largest honey exporters. Furthermore, the average price of Yemeni honey was significantly higher than the highest price among the world's 20 largest exporters (that of New Zealand) for all years except 2007. There are over 40000 beekeepers in the country working on an estimated 1.21 million traditional beehives. The export value of Yemeni honey has risen by an average of $26 \%$ per annum over the past five years, reaching USD 8.4 million in 2005.

A report by Reuters in 2018, based on the Federation of Yemeni beekeepers, indicates that Yemen exported 50,000 tons of honey per year before the war took place in 2015 , but exports have since fallen by more than 50 percent, and around 100,000 people are working in honey farms.

\section{Research Problem}

Honey production is considered an economic resource for countries and a livelihood for many families and communities in many parts of the world. Yemen has a favorable natural resource endowment for beekeeping and comparative advantage in the production of honey. However, the lack, or if available, ineffective institutional support to the honey production sector in Yemen has resulted in backward production practices in general. According to Reuters (2018), Yemeni honey export has fallen by more than 50\%. The production of $\mathrm{Al}$-Osaimat honey, in particular, still adheres to traditional methods and means though it is one of the brand names of honey which has gained popularity during the last two decades. Since 2011, the country instability has affected every aspect of people's life including the targeted area of the current study i.e. Al -Osaimat District. Thus, this study tries to shed light on the status and required intervention of the honey value chain development in one of the most famous areas of honey in the north of Yemen i.e. Al-Osaimat. Furthermore, to the best knowledge of the researcher, this study is considered to be the first to investigate solely the honey value chain in Al Osaimat District in Ammran Governorate in Yemen. 


\section{Research questions}

This research addresses the following questions:

A. What is the status of the honey value chain in AL Osaimat District at Ammran Governorate in Yemen?

B. What are the major constraints and recommended intervention(s) for the honey value chain in AL Osaimat District at Ammran Governorate in Yemen?

\section{Research Objectives}

This research attempts to achieve the following objective:

A. To explore the status of the honey value chain in AL Osaimat District at Ammran Governorate in Yemen.

B. To identify the major constraints and recommended intervention(s) for the honey value chain in AL Osaimat District at Ammran Governorate in Yemen.

\section{Research Limitations}

Due to the money, time, and security constraints, this study is limited to the honey value chain in Al Osaimat District at Ammran Governorate although the brand of Osaimat honey is generally tagged to the majority of honey production in the north part of Yemen. The fieldwork for the study was carried out in December 2018.

\section{Research Methodology}

This study sought to explore the different actors in the honey value chain in Al- Osaimat District. To achieve this, as recommended by Hellin and Meijer (2006), a mixed methods-approach with qualitative and quantitative tools was used for collecting data on different categories of actors along the value chain.

A structured questionnaire was used to collect quantitative data from beekeepers, and semi structured interviews and focus group discussions (FGDs) were used to obtain qualitative data on different opinions about the value chain. Key informant interviews (KIls) were conducted with veterinarians to further gather in-depth data about all aspects of honey chain in the area. The study fieldwork was carried out in December 2018.

Frequencies, percentages, averages and charts were used in analyzing quantitative data by Statistical Package for Social Science SPSS Version 21. For FGDs, the researcher transcribed the participants discussions and afterward the main themes were summarized. 


\section{Sampling}

A convenience non-probability sampling method was used in the study where a total number of 72 apiarists were selected due to the geographical and security constraints in Al Osaimat. Two FGDs (each consisted of 10 participants) were conducted in Al Ashaa Center where farmers and beekeepers seek veterinary help along with key informant interviews KIls (with 3 veterinarians) from the center.

\section{Findings and Discussion}

A. Firstly, to answer the question "What is the status of the honey value chain in Al Osaimat District at Ammran Governorate in Yemen?", the following section discusses the status of value chain in Al Osaimat.

\section{Honey value chain analysis}

Value chain analysis includes an assessment of the factors that affect value chain performance, including tangible constraints such as access to finance, technology, and markets, and less tangible dynamics that involve the nature of relationships and incentives that can equally constrain competitiveness (Kula et al., 2006). The following parts show the honey value chain in Al Osaimat District at Ammran Governorate in Yemen:

\section{Honey production}

According to data analysis, there are two honey harvesting periods in Al Osaimat: August for Maraii honey (flora honey) and October for Sidr honey (premium honey). The beekeepers keep moving their beehives after October's harvesting time to western coastal areas where the weather is warmer and the feed is good till April of the next year. In April, they move the hives to the middle governorates, i.e. Ibb and Dhamar, and then go back home. These tours cost beekeepers a lot of money. This operational cost had moved some of the beekeepers to change their way of practicing apiculture where they buy bees along with the hives before the main season of October and as soon as they harvest the honey, they sell out the hives with the bees. Honey production in Al Osaimat is a male-dominated activity like the case in some African countries such as Uganda and Zambia (Chemurot, 2001; Ogaba \& Akongo, 2001). 


\section{Beekeeping experience}

As Figure (1) shows, the majority of the beekeepers (27.8\%) have experience that ranges from 610-years or less than two years. The current economic condition has attracted people to take beekeeping as a source of livelihood. A little percentage of beekeepers (12.5\%) have more than 15 years of experience.

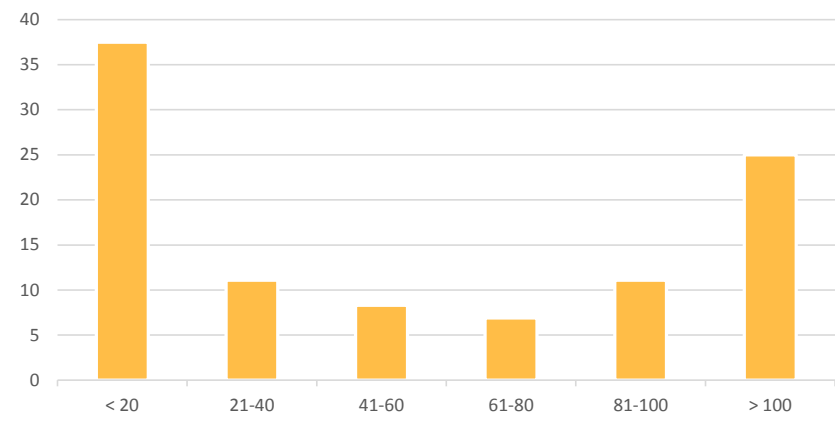

Figure 1: Beekeeping Experience

\section{Type of beehives}

The study showed the domination of traditional beekeeping practices as presented in Figure (2). This finding is similar to findings of the study conducted by Affognon et al. (2015) which found the domination of traditional beekeeping in countries such as Sudan, Uganda, Somali, and Ethiopia that largely use traditional beehives compared to countries such as Kenya, South Africa, and Tunisia. Data analysis indicates that $75 \%$ of the actors have traditional Plywood hives, and the traditional honey production is predominant. A minor percentage of actors (1\%) use pure modern beehives and $24 \%$ of them use mixed beehives. Due to traditional hives design, the hives are low yielding in terms of honey production which is the main verifiable indicator. Modern hives productivity is very high compared to the traditional one and the income of a modern hive is almost three times of what one would get from the traditional hive as Abebe (2011) found in some parts of Ethiopia; however, this is still unaffordable. It is very clear that the apicultural practices are still primitive in Al Osaimat District.

The average production of single modern hives is 2 kilograms of honey in total while the single traditional beehive average production is 1 kilogram. Normally $1.5 \mathrm{~kg}$ of honey comb produces one kilogram of liquid honey. The average production per beekeepers is 15.3 bottles of a 4 -liter plastic gallon. Figure (2) below shows the percentages of beehives types in the area. 


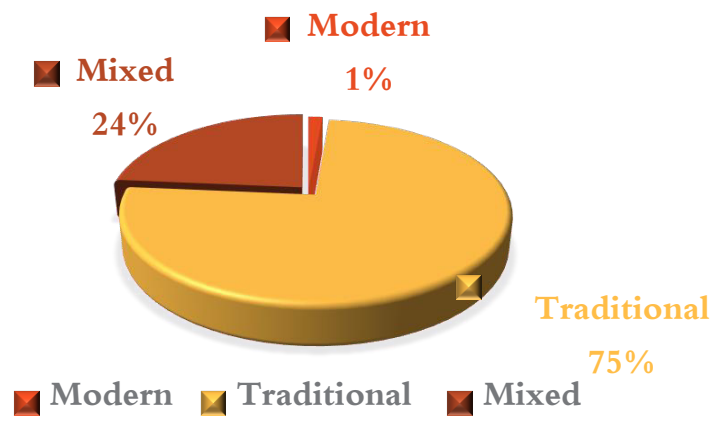

\section{Types of honey}

Figure 2: Beehives types

The primary products of beekeeping are honey and wax, but pollen, propolis, royal jelly, venom, queens, bees, and their larvae are also marketable primary bee products. In Al Osaimat, liquid honey is the only product which is being marketed and processed-wise. It is prepared by cutting the wax capping and removing honey by exposing the honeycombs to the sun lights and collecting the liquid honey. Honey of this type is normally packed in a 4-liter plastic container, which is most widespread. Besides liquid honey, no other product is being marketed due to many reasons such as the undeveloped market, lack of knowledge and training; even honeycomb wax is never commercially being used, where $100 \%$ of the surveyed beekeepers' household use it to feed cows and as children's sweeteners.

\section{Number of beehives, productivity, and income}

The analyzed data show that $37.5 \%$ of input actors own less than twenty hives and $25 \%$ of the beekeepers have more than 100 hives as Figure (3) indicates. The average production is 15.3 bottles of 4 litter (average of $84.15 \mathrm{~kg}$ ) per beekeepers. It is worth mentioning here that $36 \%$ of the survey household consists of 10 to 15 family members forming what can be considered a huge family. Due to Sidr honeyss medicinal properties, the mean price of last harvesting time in 2018 was 112.500 Yemeni Rial for a 4-liter bottle (about $\$ 150$ where $\$ 1=$ YR750 on $292018 / 10 /$ ), that is roughly $\$ 25$ per $\mathrm{kg}$. This paid price is four times higher than the price paid per $\mathrm{kg}$ in countries such as Uganda and Kenya where the average price per $\mathrm{kg}$ is estimated at \$6 US (Amulen et al., 2019). 


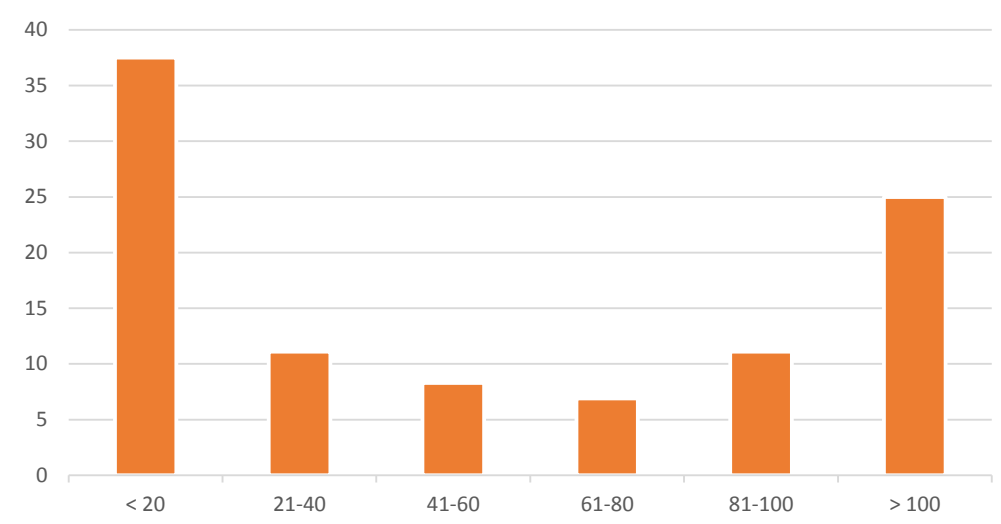

Figure 3: Number of owned beehives

\section{Honey value chain actors and their roles}

Value chain actors are all the individuals or organizations, enterprises, and public agencies related to a value chain and therefore important for understanding the functioning and performance of the value chain. They are often - but not necessarily - associated with particular value chain activities (Stein \& Barron, 2017).

The honey value chain is very short where different actors and their roles are involved in the value chain of honey in Al Osaimat. The chain actors follow a quality grading system, such as honey color, smell, and thickness, which goes with prices paid. The major actors involved in honey in the study area are input suppliers, producers (beekeepers), individual honey collectors (whole sellers), and final consumers. Beekeepers require 40 to 50 days for placing the beehives and extracting the honey. Some of them usually have other business lines. Honey traders usually purchase honey in bulk and introduce it to the market over a period of time. Honey prices depend on many factors other than quality grading, for instance, FGDs revealed that beekeepers who are in cash crunch tend to be more lenient in price negotiations with the buyers. Table (1) shows the value chain map in Al Osaimat District. 
Table 1: Honey value chain actors and functions map

\begin{tabular}{|c|c|c|c|c|}
\hline & 1 & 2 & 3 & 4 \\
\hline $\begin{array}{l}\text { Value chain } \\
\text { actors }\end{array}$ & Inputs provision & Production & $\begin{array}{l}\text { Processing/ } \\
\text { Assembling }\end{array}$ & Trading \\
\hline $\begin{array}{c}\text { Chain } \\
\text { function }\end{array}$ & $\begin{array}{l}\text { Input dealers supply } \\
\text { keeping equipment } \\
\text { like: hives, smokers, } \\
\text { extension, and some } \\
\text { veterinary medicines } \\
\text { if available }\end{array}$ & $\begin{array}{l}\text { Beekeeping, bulking, } \\
\text { cleaning, packing, } \\
\text { transferring beehives from } \\
\text { field to field according to } \\
\text { honey seasons around west } \\
\text { coastal areas and central } \\
\text { regions (packing in } 4 \mathrm{lt} \\
\text { gallon gives } 6 \mathrm{~kg} \text { ) }\end{array}$ & $\begin{array}{l}\text { Bulking, } \\
\text { Extracting, and } \\
\text { Packaging } \\
\text { predominantly } \\
\text { in } 4 \text { lt plastic } \\
\text { bottles, or in } 1 \mathrm{~kg} \\
\text { the comb cans }\end{array}$ & $\begin{array}{l}\text { Transporting to their premises, } \\
\text { storage, and selling to final } \\
\text { consumers locally or } \\
\text { regionally; Rare reprocess } \\
\text { takes place; } \\
\text { Individual honey collector, } \\
\text { wholesaling, retailing and } \\
\text { exporting the packaged honey } \\
\text { in 4lt plastic bottles }\end{array}$ \\
\hline Actor profile & $\begin{array}{l}\text { Normally beekeepers } \\
\text { sell beehives with } \\
\text { bees. Other honey } \\
\text { production } \\
\text { requirements are } \\
\text { traded small } \\
\text { individual shop } \\
\text { owners with a limited } \\
\text { variety of choices. }\end{array}$ & $\begin{array}{l}\text { Individual male apiarists, } \\
\text { with } 75 \% \text { of traditional } \\
\text { beehives. Single beehive } \\
\text { produces average } 1 \mathrm{~kg} \\
\text { honey. } 48.6 \% \text { and } 63.9 \% \\
\text { have not attended any } \\
\text { training in apiarists or } \\
\text { honey marketing } \\
\text { respectively. }\end{array}$ & $\begin{array}{l}\text { Honey } \\
\text { extracting is } \\
\text { done by some } \\
\text { old traditional } \\
\text { method of } \\
\text { exposing } \\
\text { honeycomb to } \\
\text { sunlight, hand } \\
\text { squeezing, and } \\
\text { smashing } \\
\text { honeycomb. }\end{array}$ & $\begin{array}{l}\text { Majority of which are } \\
\text { individual middlemen honey } \\
\text { collector. Not very common to } \\
\text { operate in partnerships with } \\
\text { Beekeepers. }\end{array}$ \\
\hline $\begin{array}{c}\text { Main } \\
\text { constraint }\end{array}$ & $\begin{array}{l}\text {-Old practices of } \\
\text { apiculture results in } \\
\text { low demand for the } \\
\text { modern requirement. }\end{array}$ & $\begin{array}{l}\text {-High operational costs } \\
\text {-Non-availability of } \\
\text { supportive financial } \\
\text { services } \\
\text {-Bee diseases } \\
\text {-Intensive use of the } \\
\text { pesticide for Qat shrubs } \\
\text {-Lack of proper training } \\
\text {-High intensity of } \\
\text { outsiders' beekeepers } \\
\text { during Sidr season }\end{array}$ & $\begin{array}{l}\text {-Old fashioned } \\
\text { mains of honey } \\
\text { processing and } \\
\text { extracting } \\
\text {-Poor-packaging }\end{array}$ & $\begin{array}{l}\text {-Poor honey processing } \\
\text {-Poor knowledge of marketing } \\
\text { mix especially packaging } \\
\text {-Imports of Pakistani, Kashmiri } \\
\text { honey, and cheating/mixing of } \\
\text { local Sidr honey }\end{array}$ \\
\hline $\begin{array}{c}\text { Main } \\
\text { opportunities }\end{array}$ & $\begin{array}{l}\text {-Local production of } \\
\text { wax } \\
\text {-Production of } \\
\text { modern hives locally }\end{array}$ & $\begin{array}{l}\text {-Better packing for the } \\
\text { honey } \\
\text {-Promotion for the modern } \\
\text { beehives } \\
\text {-Reproduction for the local } \\
\text { wax }\end{array}$ & $\begin{array}{l}\text {-Modern } \\
\text { extracting } \\
\text { processing } \\
\text { methods }\end{array}$ & $\begin{array}{l}\text {-Better packing for the honey } \\
\text {-Honey by-product new lines } \\
\text { for example wax production, } \\
\text { and cosmetics. }\end{array}$ \\
\hline
\end{tabular}

\section{a. Input}

The first actor in the honey value chain involves various linkages among the beekeepers, the traders of hive carpentry, bee breeders, and equipment suppliers. The core problem for this sector is the lack of effective value chain linkages among input providers, beekeepers, processors if available, traders and service providers. The input suppliers constitute the initial node of the value chain and they are comprised of individuals who are involved in the construction of beekeeping equipment. The inputs in the honey production are mainly the production or selling equipment (beehives, smokers, and bee suits). 
This study revealed the total absence of any official government participation in the input or any financial services provided to the farmers. The findings showed high operational expenses and that the apiculture industry was being jeopardized by the excessive use of insecticides in the booming business of Qat cultivation. (1)

\section{b. Producers}

Honey producers are the major actors who perform most of the value chain functions from the procurement of the inputs to harvesting and marketing. Generally, the honey produced is sold directly by beekeepers to small shops, customers, and individual honey collectors who are normally frequent buyers from nearby cities of Sana'a and Ammran, and a fraction of production is directly exported to Gulf countries, especially in the last three years.

Analyzed data indicated that majority of the respondents (52.8\%) were young beekeepers aged between 21 and 30, and most of whom are high school graduates.

The analyzed data, as presented in Figure (4), also revealed that $48.6 \%$ of the respondents have not ever taken any kind of training on beekeeping or apiculture. The long-lasting official authorities' negligence has resulted in poor business practices, increasing operational costs and low produced quality honey.

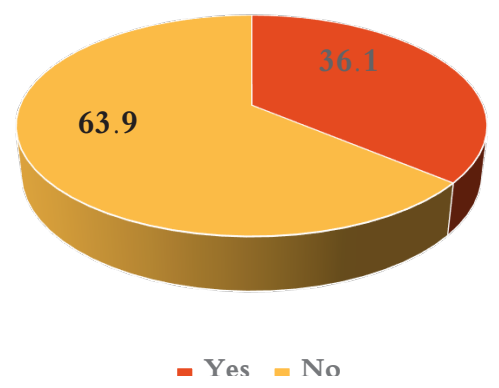

Figure 4: Beekeeping training

The study revealed the lack of basics of marketing concept knowledge amongst beekeepers and also showed that marketing practices are still very recessive. Particular aspects of clean honey extracting process and packaging, as those concepts affect the ultimate value to the producers and to the endusers, are still absent. The findings indicated, as shown in Figure (5), that (1) According to United Nation Office for Drugs and Crime (UNODC, 1956), Khat (Qat) is a shrub the leaves of which are used as 
63.9\% of the apiarists neither have knowledge nor have attended any honey marketing training. Nevertheless, $36.1 \%$ of the respondents indicated that they have had marketing training; the qualitative methods of marketing, however, indicated a weak knowledge of honey marketing.

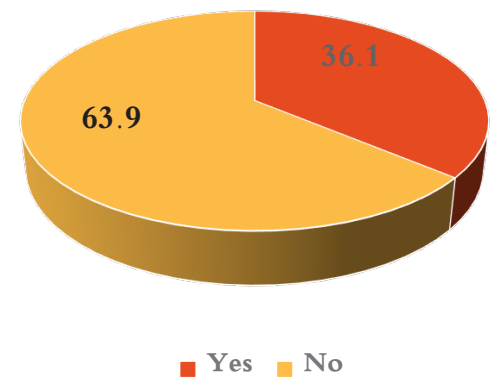

Figure 5: Marketing training

\section{c. Processing/Assembling}

Old methods of honey extracting are the common way of extracting the honey in Al Osaimat. The study findings revealed that no other honey processes take place other than sun heating or comb hand squeezing to extract honey.

\section{d. Traders}

The market survey conducted in Al Osaimat revealed that most of the buyers buy unbranded honey from the producers they know personally. Traders constitute the retailers, wholesalers, exporters and individual collectors who buy honey directly from smallholder producers at the farm. They are the majority percentage buyers of the honey and they sometimes add value to the honey-like storage, promotion, and packaging honey into glass or plastic containers. Wholesalers generally receive honey directly from local collectors and normally export the collected honey to nearby countries i.e., the Gulf States.

\section{Chain supporters}

Chain supporters provide financial or non-financial support services, such as bankers and credit agencies, business service providers, government, researchers, and extensions. The study findings revealed the absolute absence of such chain supporters in this area. This is probably due to the low financial inclusion in Yemen as a whole and in the rural areas in particular. 


\section{Honey marketing channels}

The produced honey of AL Osaimat Sider is considered as top honey and a medical property that is trusted by end-users. It was found that hardly any of the bulked harvested honey was refined further locally or properly packed into well-recommended honey containers for sale in the target markets; so, this part of the marketing mix is still very retrograde. A report by Reuters (2018) indicated that Yemen exported 50,000 tons of honey per year before the war took place in 2015 . The honey market comprises two main nodes:

(1) The local bulking agents and market constitute the most popular direct market as it offers the easiest way to sell the honey harvest via middlemen/ individual honey collectors.

(2) The external and export traders' market usually exports the collected honey to the Gulf States, i.e. Saudi Arabia, the United Arab Emirates, Oman, and Qatar.

According to the findings of this study, Al Osaimat has 5 channels in which honey flows to reach the end consumer. Table (2) shows these five honey marketing channels.

Table 2: Honey marketing channels

\begin{tabular}{|l|l|l|l|l|l|}
\hline $1^{\text {st }}$ Channel: & Producer & End Consumer & $=2.8 \%$ & \\
\hline $\begin{array}{l}2^{\text {nd }} \\
\text { Channel: }\end{array}$ & Producer & Retailers & Consumer & $=9.7 \%$ & \\
\hline $\begin{array}{l}3^{\text {rd }} \\
\text { Channel: }\end{array}$ & Producer & Wholesalers & $\begin{array}{l}\text { Retailers } \\
\text { Consumer }\end{array}$ & $=1.4 \%$ & $=68.1 \%$ \\
\hline $\begin{array}{l}4^{\text {th }} \\
\text { Channel: }\end{array}$ & Producer & Collector & $\begin{array}{l}\text { Wholesalers/Retailers } \\
\text { Consumer }\end{array}$ & $=18 \%$ \\
\hline $\begin{array}{l}5^{\text {th }} \\
\text { Channel: }\end{array}$ & Producer & Exporters & $\begin{array}{l}\text { Wholesalers/Retailers } \\
\text { Consumer }\end{array}$ & \\
\hline
\end{tabular}

B. Secondly, to answer the question "What are the major constraints and recommended intervention(s) for the honey value chain in Al Osaimat District at Ammran Governorate in Yemen?".

The study identified the following major constraints and recommended intervention(s) for the honey value chain in Al Osaimat District at Ammran as shown in Table (3). 
Table 3: Constraints and potential interventions recommended by the honey value chain actors

\begin{tabular}{|c|c|}
\hline Constraints & $\begin{array}{l}\text { Recommended intervention(s) } \\
\text { for the Government bodies }\end{array}$ \\
\hline $\begin{array}{l}\text { Underdeveloped market links - } \\
\text { particularly for inputs requirements, } \\
\text { processing, and channels of distribution }\end{array}$ & $\begin{array}{c}\text { Establishing a bee cooperative } \\
\text { association that helps beekeepers in } \\
\text { doing their business effectively and } \\
\text { efficiently and marketing the final } \\
\text { products }\end{array}$ \\
\hline $\begin{array}{c}\text { Beekeepers' poor access to veterinary } \\
\text { services and "now-how" due to low } \\
\text { levels of education }\end{array}$ & $\begin{array}{l}\text { Facilitating technical capacity } \\
\text { building for beekeepers and private } \\
\text { veterinarians, through various means } \\
\text { including private colleges }\end{array}$ \\
\hline $\begin{array}{c}\text { High cost and non-existent capacity } \\
\text { of inputs, services, access to financial } \\
\text { services, honey modern hives and } \\
\text { packing for start-up and established } \\
\text { apiarists }\end{array}$ & $\begin{array}{c}\text { Facilitating the provision of grant and/ } \\
\text { or loan support to beekeepers and } \\
\text { service providers }\end{array}$ \\
\hline Poor processing capacities & $\begin{array}{l}\text { Facilitating the provision of grant and/ } \\
\text { or loan support to the beekeepers and } \\
\text { service providers for the acquisition of } \\
\text { proper consolidation and processing } \\
\text { equipment or a joint processing unit for } \\
\text { the area or on household bases }\end{array}$ \\
\hline Inefficient business practices in general & $\begin{array}{l}\text { Providing technical training in } \\
\text { apiculture and marketing to the } \\
\text { beekeepers in the area }\end{array}$ \\
\hline $\begin{array}{c}\text { Insufficient capacity of quality } \\
\text { assurance laboratories and quality } \\
\text { assurance }\end{array}$ & $\begin{array}{l}\text { Advocating for the establishment of } \\
\text { a full capacity laboratory closer to } \\
\text { producers for instance in Ammran } \\
\text { University }\end{array}$ \\
\hline $\begin{array}{l}\text { Inadequate national regulations and } \\
\text { non-existent food quality and safety } \\
\text { monitoring mechanisms that help to } \\
\text { brand Al Osaimat honey abroad }\end{array}$ & $\begin{array}{l}\text { Developing the required regulations, } \\
\text { rules, and standards that can help } \\
\text { honey production which meets } \\
\text { international standards }\end{array}$ \\
\hline
\end{tabular}

Table (3) shows that there are several constrains for the honey value chain in Al Osaimat District at Ammran. Some of these constrains were to some extent reported by Abebe (2009) who investigated the market chain analysis of honey production in Atsbi Wemberta District at the Eastern zone of Tigray National Regional State. The constrains reported by Abebe include lack of adequate beekeeping skill, lack of adequate training and better knowledge about beekeeping practices, quality problem (adulteration), lack of supervision or follow up, and shortage of finance. However, the constrains found by the present study are different than those found by ACDI/VOCA (2017) in which the only constrain for the honey value chain in Liberia is 
the limited number of small micro enterprises (SMEs) buying, bottling and distributing honey.

In Table (3), some interventions are recommended for improving the honey value chain in Al Osaimat District at Ammran and attempting to overcome such constrains. These recommended interventions include establishing a bee cooperative association that would help beekeepers in doing their business effectively and efficiently, facilitating technical capacity building for beekeepers and private veterinarians, facilitating the provision of grant and/or loan support to beekeepers and service providers, providing technical training in apiculture and marketing to the beekeepers in the area, advocating for the establishment of a full capacity laboratory closer to producers for instance in Ammran University and finally developing the required regulations, rules, and standards that can help honey production which meets international standards.

\section{Conclusion}

Al Osaimat has a long experience of traditional beekeeping and adequate natural resources. Nevertheless, due to the lack of government institutional supports, low educational levels, limited access to technology, poor infrastructure, limited access to market and value chain development, the district, in general, has not been sufficiently benefited from beekeeping. Opportunities and potentials to boost honey production and market the products are huge. Providing know-how and marketing skills to the target beneficiaries can help exploit the untapped potential of the beekeeping profession in Al Osaimat District. Improving beekeeping input equipment, tools, and bee veterinary service, honey extracting process, and the marketing mix especially the packaging aspect of it can also elevate the apicultural in Al Osaimat.

Enhancing beekeepers' knowledge and skills about beekeeping management, (including colony multiplication techniques) and pre-and post-harvest handling of hive products can boom the honey business in the area. Encouraging women and marginalized youth people to participate in beekeeping and enhancing the capacity of the existing beekeepers to increase the sustainable and adequate supply of quality honey is important for rapid promotion of apiculture in Al Osaimat.

The non-availability of beekeeper cooperatives that may help them in business with the total absence of government agencies has doubled the beekeepers; 
struggle to sustain a profitable business. Establishing honey cooperatives and equipping them with the necessary facilities should be done to elevate the apicultural industry in the district. This study was limited to the value chain of Al Osaimat in Ammran governate and the results can not be generalized to the chains in Yemen. Future work may include studies on honey value chain in South governates of Yemen, such as honey value chain in Tarim, Dawan, and Abyan.

\section{References}

Abebe, W. (2009). Market chain analysis of honey production: In Atsbi Wemberta District, Eastern Zone of Tigray National Regional State (Master thesis). Haramaya University, Dire Dawa, Ethiopia.

Abebe, W. (2011). Financial benefits of box hive and the determinants of its adoption in selected district of Ethiopia. American Journal of Economics, 1(1), 21-29.

ACDI/VOCA (2017). Value chain gap analysis of targeted agricultural product value chains in Liberia: Final report. Prepared for the Forest Incomes for Environmental Sustainability (FIFES) Project, USAID. Retrieved July 7, 2019, from http://pdf.usaid.gov/pdf_docs/PA00SZ8Z.pdf

Affognon, H. D., Kingori, W. S., Omondi, A. I., Diiro, M. G., Muriithi, B. W., Makau, S., \& Raina, S. K. (2015). Adoption of modern beekeeping and its impact on honey production in the former Mwingi District of Kenya: assessment using theory-based impact evaluation approach. International Journal of Tropical Insect Science, 35(2), 96-102.

Amulen, D. R., D'Haese, M., DıHaene, E., Acai, J., Agea, J. G., Smagghe, G., \& Cross, P. (2019). Estimating the potential of beekeeping to alleviate household poverty in rural Uganda. PloS One, 14(3), e0214113.

Chemurot, M. (2011). Beekeeping in Adjumani district, Uganda. Bee World, 88(3), 58-61.

Hellin, J., \& Meijer, M. (2006) Guidelines for value chain analysis. Food and Agriculture Organization of the United Nations (FAO), Rome, Italy.

Henriksen, L.F., Riisgaard, L., \& Ponte, S., (2010). Agro-food Valve Chain Interventions in Asia and the Pacific: A review and analysis of case studies (Working Paper). United Nations Industrial Development Organization (UNIDO), Vienna, Austria.

IFAD (2008). Republic of Yemen: economic opportunities programme (EOP). Programme final design report. Retrieved May 18, 2019, from https:// www.academia.edu/11793130/Yemen_Development_Rural_Business Opportunities 
Kaplinsky, R. (2000). Globalisation and unequalisation: what can be learned from value chain analysis? Journal of Development Studies, 37(2), 117 146.

Kaplinsky, R., \& M. Morris (2001). A handbook for valve chain research. Brighton, United Kingdom: Institute of Development Studies, University of Sussex.

KIT \& IIRR (2010). Value chain finance: Beyond microfinance tor rural entrepreneurs. Royal Tropical Institute, Amsterdam; and International Institute of Rural Reconstruction, Nairobi.

Kula, O., Downing, J., \& Field, M. (2006). Globalization and the small firm: A value chain approach to economic growth and poverty reduction. USAID, Washington DC.

Ogaba, M. R., \& Akongo, T. (2001). Gender issues in beekeeping: The Uganda case. In APIMONDIA Congress, 28 October - 1 November, Durban, South Africa.

Porter, M. E. (1985). Competitive advantage. New York: Free Press.

Porter, M. E. (1998). Competitive advantage, creating and sustaining superior performance with a new introduction. New York: Free Press.

Reuters (August 7, 2018). Beekeeping in Yemen becomes a dangerous profession in war. Retrieved May 18, 2019, from https://www.reuters.com/article/usyemen-security-honey-idUSKBN1KS1N2

SMEPS \& KIT (2009). Analysis of 5 value chains in Yemen (Fish, honey, coffee, wheat and qat). Report for the World Bank. Retrieved June 1st, 2019, from http://www.value-chains.org/dyn/bds/docs/769/yemenvaluechainsstudy. pdf

Stein, C., \& Barron, J. (2017). Mapping actors along value chains: Integrating visual network research and participatory statistics into value chain analysis. Giza, Egypt: International Water Management Institute (IWMI).

UNIDO (2011). Pro-poor value chain development: 25 guiding questions for designing and implementing agroindustry projects. United Nations Industrial Development Organization (UNIDO), Vienna, Austria.

UNODC (1956, January 1). Khat. Retrieved August 18, 2019, from https://www. unodc.org/unodc/en/data-and-analysis/bulletin/bulletin 1956-01-01_4 page004.html 